Courtesan, Concubine, Whore: Apollodorus' Deliberate Use of Terms for Prostitutes Author(s): Jess Miner

Source: The American Journal of Philology, Vol. 124, No. 1 (Spring, 2003), pp. 19-37

Published by: The Johns Hopkins University Press

Stable URL: http://www.jstor.org/stable/1561932

Accessed: 20-05-2015 19:49 UTC

Your use of the JSTOR archive indicates your acceptance of the Terms \& Conditions of Use, available at http://www.jstor.org/page/ info/about/policies/terms.jsp

JSTOR is a not-for-profit service that helps scholars, researchers, and students discover, use, and build upon a wide range of content in a trusted digital archive. We use information technology and tools to increase productivity and facilitate new forms of scholarship. For more information about JSTOR, please contact support@jstor.org. 


\title{
COURTESAN, CONCUBINE, WHORE: APOLLODORUS' DELIBERATE USE OF TERMS FOR PROSTITUTES
}

\author{
Jess Miner
}

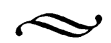

\begin{abstract}
This article examines Apollodorus' use of the terms hetaira, pallake , and porne in the speech Against Neaira. It argues that he employs these terms with consistency and with attention to differences among them rather than haphazardly or interchangeably as was previously believed. Apollodorus' distinctions among types of prostitutes are further clarified through comparisons with his use of the terms in other speeches. Finally, there is a reexamination of the famous statement on the existence of three types of women in society. By resituating this claim in its oratorical context, I show that it is not an all-inclusive remark on women's roles but rather a statement quite specific to Apollodorus' attack on Neaira.
\end{abstract}

IN THE OPENING SECTION on "desire" in Davidson's well-received book Courtesans and Fishcakes, he quotes the famous passage from [Demosthenes] 59, Apollodorus' speech Against Neaira, about the three categories of women in Athens: "For we have courtesans (hetairai) for pleasure, and concubines (pallakai) for the daily service of our bodies, [and] wives (gunaikes) for the production of legitimate offspring and to have a reliable guardian of our household property" (122). After he points out how influential this passage has been and how it has been wrongly understood as straightforward by some modern historians, he adds:

The speaker himself shows a remarkable level of inconsistency in conferring his titles on Neaera and the whole thrust of the speech is that such distinctions are easily flouted, enabling Neaera's daughter, 'a common whore' (pornē), to infiltrate the ranks of decent citizens by marrying the King Archon, even presiding with him over the most ancient rites in the city's religious calendar and risking the wrath of the gods. ${ }^{1}$

${ }^{1}$ Davidson 1997, 73. 
There is much of value in Davidson's study of prostitution in society, but his analysis of the terminology of prostitution and how it is used by Apollodorus is misleading. ${ }^{2}$ Far from implementing these terms with "a remarkable level of inconsistency," Apollodorus (like many of the orators) is strikingly consistent in his use of prostitution terminology. ${ }^{3}$ Furthermore, this consistency is an integral part of his rhetorical strategy. ${ }^{4}$ This is not to say that the terms themselves or the categories of women they represent are precise. ${ }^{5}$ Nevertheless, an understanding of how Apollodorus implements terminology for his immediate rhetorical needs helps us uncover distinguishing features that have been previously overlooked. ${ }^{6}$

[Demosthenes] 59 is a sustained attack on the life of the courtesan Neaira. The purpose of the attack is clearly to bring down Apollodorus' political enemy Stephanus. Apollodorus first gives a long narrative account [16-49] about the early life of Neaira in order to establish that she is not an Athenian citizen but rather a metic from Corinth. $\mathrm{He}$ has sufficient evidence to prove this, and, in fact, it is not really a point of dispute. ${ }^{7} \mathrm{He}$ proceeds with this line of argument because it gives him the

${ }^{2}$ See also Gilhuly 1999, 23: "Since Apollodoros is positioning his speech within democratic ideology, he sets up an opposition between a citizen's wives and daughters and prostitution of any sort. Consequently, Neaira and her daughter Phano are described under a variety of terms, including hetaira, porne , and pallake, designating their profession without appealing to the nuanced distinctions within the profession." And Fisher $(2001,185)$, when comparing the use of terminology in this speech with that of Aeschines 1, claims: "Apollodoros' prosecution of Neaira displays a comparable and equally convenient oscillation between treating Neaira as a classy and expensive hetaira and as a common prostitute (pornē)."

${ }^{3}$ The present investigation focuses on [Demosthenes] 59; however, I hope to show in the future that much of what we see in this speech holds true for other speeches involving prostitutes as well. Aeschines, for example, in his speech Against Timarchus, distinguishes early on between a male hetaira and pornos (51-52) and then proceeds to depict Timarchus throughout the rest of the speech as a pornos. His consistent use of pornos, the more disgraceful and slanderous of the two terms, is crucial to his rhetorical strategy and the success of his argument.

${ }^{4}$ Many factors affect the orators' manipulation of terminology. Particularly important are the status of the prostitute, the relationship of the speaker to the prostitute, the amount of factual evidence a speaker has, and timing (the points in the speech when the use of a particular term will be most effective).

${ }^{5}$ Davidson (1997, 73-77) shows convincingly how slippery these terms can be.

${ }^{6}$ As Brown $(1990,248)$ has noted, a systematic study of fourth-century prostitutional nomenclature has yet to be done. In the present paper, I hope to demonstrate how important a close reading of these terms in context is (particularly in oratory) as one step toward a more comprehensive understanding.

${ }^{7}$ Carey 1992, 8-12, and Patterson 1994, 207. 
opportunity to describe Neaira's lascivious lifestyle in detail. His negative characterization, in turn, enables him to compensate for a lack of evidence against Stephanus. ${ }^{8}$ It is from this detailed depiction that we get a chronological account of the life of a hetaira beginning with the early years of childhood. We must pay close attention to the distinctions Apollodorus makes here between pornē and hetaira. ${ }^{9}$

Before Neaira comes of age, Apollodorus states twice that she sells her body while under the care of her owner Nikaretē:

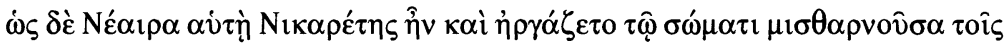

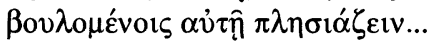

but the fact that this woman Neaira belonged to Nikaretē and worked with her body on hire to all who wished to have relations with her ... ${ }^{10}$

${ }^{8}$ That he lacks factual evidence against Stephanus becomes clear in the rather short and inadequate proof section of his argument (cf. Carey 1992, 11; Patterson 1994, 207-9; and Kapparis 1999, 31-43). See further below, 24-26.

${ }^{9}$ There has been much recent attention focusing on these two terms, most notably Davidson (1997, 73-136) and Kurke (1999, 175-219) who base their analyses on a gift vs. commodity exchange model, the hetaira representing the former, the porne, the latter. While Davidson argues that the opposition is discursive only, Kurke $(1999,181)$ sees this distinction "simultaneously instituted at the level of practice in Greek culture." She further argues that hetairai and pornai represent "distinct spheres of social life." Others see these roles as marking different degrees on a continuum because of the overlap of their function (exchange of sex for something of value); cf. Dover $(1989,20-21)$ who argues that "the dividing line between the two categories could not be sharp"; Brown 1990, 248; Gomme and Sandbach 1973, 30; Kapparis 1999, 408-9; Peschel 1987, 19-20. Arguments opposing distinctions are based on the apparently interchangeable use of both terms in some texts (e.g., Dem. 48.53-56) or the use of one term when a different term more accurately describes the relationship (cf. Kapparis 1999, 409, who points out that porne is used in Lys. 4.19 , although the relationship is long term like that of a hetaira; see also $\mathrm{n}$. 49 below). The use of terminology in these and other speeches, however, has yet to be analysed in context. Furthermore, unlike Apollodorus' speech, these texts are not detailed discussions of prostitution nor are they considered foundational to our understanding of the roles of prostitutes. Thus, I think it is important to see the distinctions evident in Apollodorus' presentation even if this usage was not the same in all authors. For more on definitions of the hetaira and pornēe see Calame 1989, 103-4; Dover 1973, 68; Hauschild 1933, 7-9; Herter 1957, $1181-82$.

${ }^{10}$ All translations are from Carey 1992; however, I have made adaptations where necessary to avoid conflation of terms with behaviors. Here, for example, Carey translates

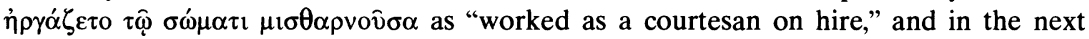
passage quoted (22), he translates this same phrase as "already working as a prostitute." Kapparis $(1999,95)$ renders the first phrase more literally as "earning money by her body," but then (like Carey) translates the second as "already working as a prostitute." By keeping all translations literal, I hope to distinguish between descriptive behavior (i.e., working 


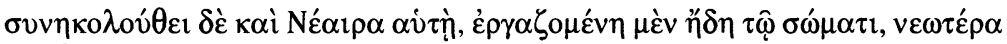

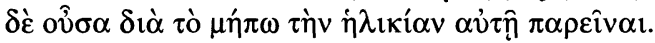

Neaira here accompanied them; she was already working with her body, though she was too young and she had not yet reached puberty.

Only after these descriptions does Apollodorus use the term hetaira: ${ }^{11}$

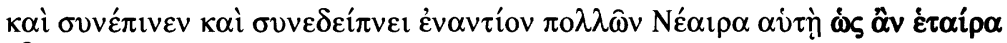

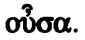

and here Neaira drank and dined with them in the presence of a number of men as though she were a courtesan.

This sentence is striking for two reasons: first, it emphasizes the activities associated with the role of the hetaira, namely eating and drinking with other men, social behavior that reinforces the etymological meaning of "companion"; second, the past contrary-to-fact condition indicated by the $\dot{\omega} \varsigma$ $\propto$ $v$ implies that Neaira was not yet a hetaira, but rather acting "as if" she were. Kapparis argues that ơ $v$ should be deleted on the grounds that it "would imply that Neaira actually was not a courtesan." 12 His justification for the deletion, however, is his own assertion that Apollodorus is saying that she is a courtesan. Before we excise $\alpha$ (which is preserved in the manuscripts), we should make an attempt to understand its function. In particular, we should consider what Apollodorus might be telling us by claiming Neaira (at this point) was not a courtesan though she was behaving like one. An examination of the same expression without ơv later in the speech sheds light on this question.

with her body) and specific terminology (i.e., hetaira, pornē) in order to elucidate how carefully Apollodorus uses these terms in his construction of Neaira and Phano. Unless otherwise noted and explained, I translate hetaira as "courtesan," pornē as "prostitute," and pallakē as "concubine."

${ }^{11}$ This use of hetaira is the first of sixteen occurrences in Apollodorus' speech (for a full listing, see n. 18). Before this passage (24), it occurs only once (13) in Theomnestus' introduction where he accuses Stephanus of giving the daughters of courtesans in marriage

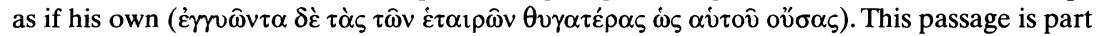
of Theomnestus' short summary of the case and refers generally (note the plural hetairai) to Neaira's later career. His speech (1-15), which has been noted as a "speech in its own right" by Carey $(1992,84)$, is distinct from Apollodorus' subsequent speech. Thus, this use of hetaira does not affect Apollodorus' characterization, which begins with Neaira's behavior as a child and progresses through her career chronologically.

${ }^{12}$ Kapparis 1999, 221; cf. also Kapparis 1995, 21. 
Apollodorus uses this same phrase three times within the text itself. ${ }^{13}$ In these instances, $\dot{\omega} \varsigma \dot{\varepsilon} \tau \alpha i \rho \alpha$ ov̉ $\sigma \alpha$ appears where Apollodorus describes Neaira's behavior but leaves open whether or not this was her status. The use of $\omega \varsigma$ plus the participle seems to be Apollodorus' indication that her status was something in question. ${ }^{14}$ In fact, he has a proclivity for this construction. For example, he says that Stephanus married off his daughter "as his own" (50), and again that Neaira was required to post bail "as a foreigner" (49). ${ }^{15}$ Only in this first instance (24) is the term hetaira used when $\not{\alpha} v$ is also present. It is likely that she was not considered a hetaira here because of her age and her social standing.

Thus far, Apollodorus has told us she has not yet come of age and is still a slave under the control of Nikaretē (22). According to Apollodorus' description, a young girl in this situation might be considered a porne $\bar{e}$, but not a hetaira, as we see in section 113:

then without a doubt the trade of prostitutes $(\tau \hat{\omega} v \pi \mathrm{o} \rho v \hat{\omega} v)$ will fall to the daughters of citizens, all those who because of poverty cannot be married, while the status of free women will fall to courtesans ( $\tau \dot{\alpha} \varsigma \dot{\varepsilon} \tau \alpha i ́ \rho \alpha \varsigma)$.

This passage, although rhetorical, clearly associates the profession of hetaira with women and porne with girls. This is not to say that women were not pornai-indeed they were. Rather, the distinction indicates that young lower class or slave girls were not thought to be hetairai. ${ }^{16}$ Thus, to excise ő $v$ from the text in 24 is to overlook a possible distinction Apollodorus is making about the ranks of prostitution more generally and to ignore the subtlety of the argument he is constructing based on Neaira's questionable status. He could have labeled her a hetaira directly, if his

${ }^{13} 37 ; 48 ; 49$. It also occurs in the testimony of a witness (25) and in a deposition (28), both times without ö $\mathrm{v}$. The authenticity of these documents is disputed. Carey $(1992,99)$ argues that they are genuine based on the transmission of vvví. Kapparis (1999, 221-22; 225-26), however, offers a convincing analysis of these documents as later forgeries based on the inconsistency of the transmission of vôv and vvví as well as other awkward phrases. If these documents are valid, this would imply that the witnesses consider Neaira a hetaira without Apollodorus taking responsibility for that claim.

${ }^{14}$ Support for this claim can be found in Isaeus 3 where the speaker uses the phrase

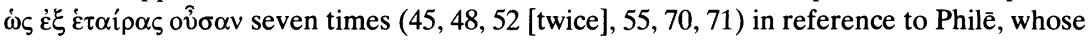
status is under attack by the accusation that her mother was a hetaira.

${ }^{15} \mathrm{Cf}$. Theomnestus' similar use of the construction in 13 (quoted above, $\mathrm{n} .11$ ).

${ }^{16} \mathrm{Cf}$. Ath. $13.588 \mathrm{c}-\mathrm{d}$ for corroboration of the idea that young girls were not considered hetairai; here Apelles the painter is mocked for bringing Lais to a symposium when she is still a parthenos and not yet a hetaira. 
point were simply to claim she was one, as he does with Sinopē in 116: ó $\tau 1$

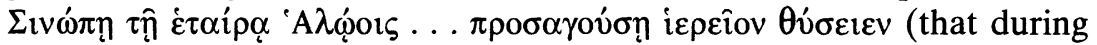
the Haloa he sacrificed for the courtesan Sinope a victim she brought). Instead, Apollodorus is more cautious in his characterization of her. In the narrative, he has used only one term, hetaira, to refer to Neaira; moreover, he has used it most often with the qualification of $\dot{\omega} \varsigma$, avoiding explicitly calling her a hetaira. ${ }^{17}$

At the opening of chapter 49, Apollodorus concludes the narrative section as follows: "So then, I have proved in my narrative with the support of witnesses that she was originally a slave and was sold twice, and that she worked as a courtesan ( $\dot{\omega} \varsigma \dot{\varepsilon} \tau \alpha i \rho \alpha o v \sigma \alpha)$." Up to this point in the text, he has used the word hetaira in association with Neaira ten times in his attempt to create the image of a lascivious woman. ${ }^{18}$ Apollodorus, however, employs the term in a relatively restrained manner, not as direct invective, but rather as a term necessary for describing Neaira's early career and for emphasizing her non-Athenian status. He is slowly building up to his more forceful attack on her character, which he saves for the end of the speech. The fact that he has not once yet called her a pallake or porne is further evidence that this long and repetitious depiction of her as a hetaira is deliberate. Nor is it an accident that the term hetaira does not appear again until 112 (more than sixty sections later) near the end of the speech when he finally returns to his discussion of Neaira. In the intervening sections (50-106), he shifts the focus away from Neaira and thus away from this term as well.

In sections 50-93, Apollodorus turns his attention to Neaira's "daughter" Phano. Unlike her "mother," Phano is never labeled a hetaira. Moreover, despite Davidson's claim (cited above) that Phano was "a common whore (pornēe), Apollodorus never labels her by this term either. In fact, Apollodorus is just as careful and consistent in his charac-

${ }^{17}$ In only two instances in the narrative does he refer to Neaira as a hetaira without $\dot{\omega}(30,39)$. In both cases, he is speaking from the perspective of her lovers and not addressing the issue of her status himself.

${ }^{18}$ I have already noted all ten $(24,25,28,30,34,37,39,48$ [twice], 49). There are six later uses at the end of the speech $(112,113,116,118,119,122)$. I will address the three that apply to Neaira specifically $(118,119,122)$ below. Of the other three, one $(116)$ refers to a different woman altogether, Sinopē, whom Apollodorus mentions when bringing up an analogous situation of a hetaira illegally involved in religious rites (see above). The other two $(112,113)$ are generalizations. I will discuss 112 below, since it is the only instance in which there seems to be conflation of the two terms hetaira and porne. For 113, see above, 23. 
terization of Phano as he was with Neaira. In reference to her character and her activities, four times he uses the generic and purposely vague

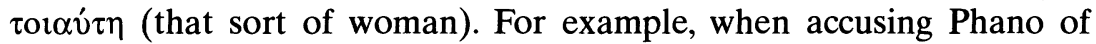
impiously performing the sacred rites of the Venerable Women, he poses the following question:

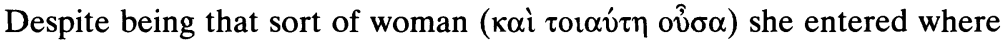
nobody else among the vast Athenian population enters, except the wife of the King-archon, and administered the oath to the Venerable Women who assist in the rites; she was given as bride to Dionysos and she carried out as the city's representative the many ceremonies, holy and secret, which were handed down by our ancestors. How can it accord with piety for just any woman actually to perform rites ... especially that sort of woman ( $\alpha \lambda \lambda \omega \varsigma$

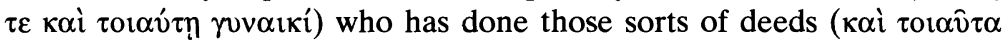

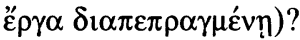

And again, when discussing the displeasure of the Areopagus toward Theogenes for his wife's (Phano's) activities (81), they proposed to pun-

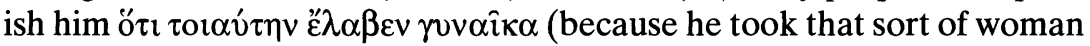
as his wife). Soon after, Apollodorus for the last time repeats the assertion that Phano should not have been involved in these rites, using almost identical phrasing as in the first instance quoted above:

not only should she have kept away from these ceremonies, being that sort

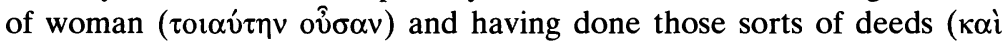
$\tau o เ \alpha \hat{v} \tau \alpha \delta\llcorner\alpha \pi \varepsilon \pi \rho \alpha \gamma \mu \varepsilon \dot{v} \eta v)$...

Scholars generally agree that Apollodorus' case against Phano is factually weak and unconvincing ${ }^{20}$ and that this weakness sheds light on Apollodorus' decision to focus his accusations against the women (Neaira

${ }^{19}$ Elsewhere, Apollodorus indirectly implies that Phano is a prostitute by attacking Stephanus' home as an ergasterion (sex shop) with Stephanus himself as the pornoboskos (brothel keeper) (67-70). Here the brunt of the attack is cleverly shifted against Stephanus for the ways in which he maintains his home, rather than against Phano directly for her supposed activities. Furthermore, Apollodorus shifts these accusations away from himself by putting them in the mouth of Epainetus (cf. Kapparis 1999, 37).

${ }^{20}$ Carey $(1992,11)$, for example, states, "the paucity of testimony does not inspire confidence." Likewise, Patterson $(1994,208)$ points out that "Apollodoros never offers either proof or testimony for his assertion that [Phano] is Neaira's daughter." And Kapparis $(1999,36)$ goes even further, arguing that Apollodorus' attempt to disprove Phano's legitimacy not only failed, but also "provided in a sense a formal recognition of her citizenship." 
and her daughter) rather than the men (Stephanus and his sons). ${ }^{21}$ Apollodorus probably chooses this route of attack because, unlike the males, the females in the family would not be recorded in the citizen registry. Thus, whether or not a woman is of citizen or noncitizen status is more difficult to determine. ${ }^{22}$ Without an official document available for public consultation, Apollodorus has greater room to attack Phano's parentage. He approaches this task carefully as is clear from the means he chooses to characterize her.

If Phano is the daughter of Neaira who was a courtesan, it is striking that Apollodorus never calls her a porne or even a hetaira for that matter. It is even more striking when we consider that he makes a specific link near the end of the speech (113) between women as hetairai and their daughters as pornai (see above) ${ }^{23}$ Apollodorus did not label Phano as such because he was well aware that she was not a prostitute. Yet even so, why would he refrain from using these terms to label her? As Kapparis points out, "Apollodoros does not say that Phano was a courtesan, although he would not have missed the opportunity to say so, if this was the case, as such an allegation would have undermined seriously her citizen status." ${ }^{24}$ Kapparis $(1999,37)$ argues further that such an allegation would not have been made easily against women and in this case, it would have been "blatantly untrue." Apollodorus perhaps knew that if he had made specific claims about Phano's status, then Stephanus could have more easily refuted his case.

Apollodorus wisely opted for the more subtle and strategic route. Whereas the orator goes to great lengths to prove decisively every stage of Neaira's career as a courtesan, in his discussion of Phano, he relies on vague descriptions and heightened rhetoric. As Patterson suggests:

${ }^{21}$ Carey (1992, 8-12), Patterson (1994, 205-9), Kapparis (1999, 31-41), and Gilhuly $(1999,42-47)$ all address Apollodorus' decision to prosecute Neaira under the law regarding sunoikein (setting up an oikos together) instead of prosecuting Stephanus directly under the law Apollodorus cites in section 52 against giving an alien woman in marriage to an Athenian man, for which the penalty is atimia. They further criticize Apollodorus' decision to focus on Phano as Stephanus' illegitimate daughter and to gloss over the issue of the legitimacy of the three sons.

${ }^{22}$ Cf. Ogden $(1996,153)$ who discusses the connection of introducing male offspring (as opposed to females) to the phratry as a means of recognizing them as citizens.

${ }^{23}$ On the passing down of the career from mother to daughter in the world of courtesans, see Ogden (1996, 94-96) who connects this practice with matronymics.

${ }^{24}$ Kapparis 1999, 37. It was not illegal for citizen women to be courtesans, but it was probably rare. See Ogden 1996, 151-61; Sealey 1984; Cohen 2000, 113-47. 
A further trick of the argument is the conflation of identities of the two women-mother and "daughter"-in order to associate Neaira herself as closely as possible with the scandal and outrage (as he paints it) of the younger woman's career. I think it is fair to say that by the end of the speech Apollodoros has created a fictional two-headed monster from the combined personae of Neaira and Phano. ${ }^{25}$

But in fact, the conflation works both ways, allowing him (perhaps more importantly) to associate Phano with Neaira's activities. He stretches the evidence by linking Phano closely to Neaira in an indirect attempt to discredit her status as a citizen. One way he connects the two women is by using matronymic allusions: he refers to Phano consistently as the daughter of Neaira, ${ }^{26}$ and in section 50 , for example, he comments that Phano could not live frugally like Phrastor, her new husband, because she sought after the habits and licentiousness of her mother Neaira

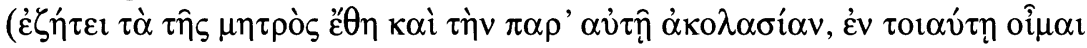
$\left.\dot{\varepsilon} \xi_{0 v \sigma i ́ \alpha} \tau \varepsilon \theta \rho \alpha \mu \mu \varepsilon^{\prime} v \eta\right) .{ }^{27}$ Apollodorus needs Neaira's career to strengthen his case against Phano. The vagueness of the terminology he uses when describing Phano illustrates that need rather explicitly. Moreover, the fact that Apollodorus carefully refrains from labeling Phano a porne or hetaira demonstrates clearly that his use of these terms was not at all haphazard.

To further intensify his attack against Neaira for wrongfully usurping Athenian citizenship, Apollodorus turns from his extended attack on Phano to implicitly contrasting Neaira and Phano with the courageous and devoted Plataians. ${ }^{28}$ Apollodorus' point is that, if the gift of citizenship were restricted even for the most loyal non-citizens, it would be an outrage for Neaira and her daughter to enjoy these privileges considering their illicit backgrounds and contempt for the laws. Drawing on a historical example, he creates a significant shift in language and tone from the degrading activities of women who work with their bodies to men who dutifully fight and suffer for their allies. This contrast becomes starker when Apollodorus finally returns to Neaira near the end of the

${ }^{25}$ Patterson 1994, 208.

${ }^{26}$ The use of the patronymic was reserved for respectable women. Cf. $n$. 23 and section 113 where pornai are contrasted with the daughters of citizen men (tōn politōn).

${ }^{27}$ This is Apollodorus' own judgment as indicated by the oî $\mu \alpha \mathrm{t}$. His use of opinions with regard to Phano contributes to the heightened rhetoric characteristic of these sections.

${ }^{28}$ See Gilhuly's insightful analysis of the more implicit function of this "digression" $(1999,47-52)$. 
speech (107). We have not heard much of her for nearly sixty chapters (almost half of the speech), but the return is powerful and vitriolic:

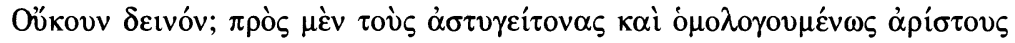

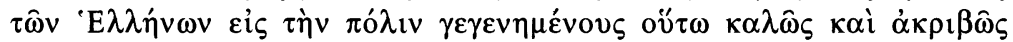

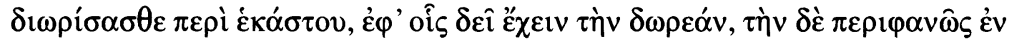

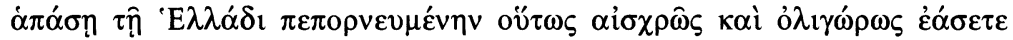

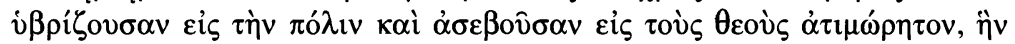

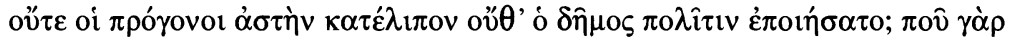
$\alpha$ $\mu \iota \sigma \theta \hat{\varphi} ; ;^{29}$

Is it not grotesque? When, in dealing with men of a neighbouring city who by common agreement had been the greatest benefactors of our city, you defined so properly and precisely each of the terms on which they should receive the grant, will you leave a woman, who has blatantly whored ${ }^{30}$ ( $\pi \varepsilon \pi \circ \rho v \varepsilon v \mu \varepsilon ́ v \eta v)$ throughout the whole of Greece unpunished for insulting the city so shamefully and contemptuously and committing sacrilege against the gods, a woman who was neither bequeathed citizenship by her ancestors nor granted it by the people? For where has she not worked with her body ( $\left.\varepsilon^{\prime \prime} \rho \gamma \alpha \sigma \tau \alpha \iota \tau \hat{\imath} \sigma \omega \dot{\omega} \mu \alpha \tau\right)$ ? Where has she not gone to earn her daily wage $\left(\kappa \alpha \theta^{\prime} \dot{\eta} \mu \varepsilon \dot{\rho} \rho \nu \mu \iota \sigma \theta \hat{\varphi}\right)$ ?

This passage is crucial to our understanding of Apollodorus' rhetorical strategy, regarding both his use of prostitution terminology and his creation of ambiguity between Neaira and Phano. As we have already seen, Apollodorus bolsters his weak evidence by effectively associating scandalous activities with both women. Carey has rightly pointed to the confusion Apollodorus creates here (which he claims is probably intentional) between the two women by launching straightaway into his at-

${ }^{29}$ I follow Kapparis (citing Blass, 1893) who argues that the excised phrase pre-

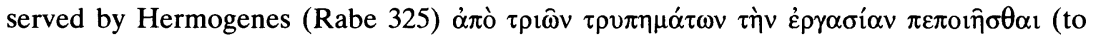
have made her living from three holes) most likely was located at the end of this section (108), if it is original to the speech. Kapparis argues convincingly for its authenticity based on strong evidence from our ancient sources, contra Carey $(1992,141-42)$ who doubts that it was used in the law court due to its graphic nature. Certainly the nature of the comment fits the context of Apollodorus' all-out attack on Neaira here at the end of the speech, considering that only now does he even call her a porne. . It would be glaringly out of place in any section of the earlier narrative as has been previously suggested. For a full discussion of the controversy and the evidence, see Kapparis 1999, 402-4.

${ }^{30}$ I keep Carey's translation here as "whored" and not "prostituted" because it better conveys the extreme sense of slander characteristic of this passage. 
tack without mentioning any names. ${ }^{31}$ The jury would be inclined to think he was talking about Phano since he last made his case against her. This impression is enhanced by the fact that he includes the accusation of committing sacrilege against the gods, recalling the incident in which he accused Phano of performing sacred rites as the Basilinna (73). It does not become clear that Apollodorus is talking about Neaira until he mentions her career under Nikaretē (108). The identification finally becomes explicit when he mentions her by name two sections later (110). Thus, Apollodorus gives the impression that he is slandering Phano, knowing that, once this impression has infiltrated the minds of the jurors, it would not be fully eradicated by the realization that he is talking about Neaira.

Perhaps more important is the shift in tone from his narrative description of Neaira as a hetaira (16-49) to the scathing invective we see in this passage. ${ }^{32}$ His highly charged denunciation of Neaira as a shameless porne is, in fact, the first time in the speech that he attacks her in this way. Until this passage, where he uses the past participle $\pi \varepsilon \pi$ o $v \varepsilon v \mu \varepsilon \dot{v} \eta v$, we only find the term pornoboskos (brothel keeper) twice, once in association with Nikaretē (30) and once with Stephanus (68) but never with Neaira. The three other uses of porne in the speech all follow closely on the heels of this slanderous attack in 107-8, but in only one of these passages is it used directly against Neaira. This use is likewise pointed; it appears in Apollodorus' emotional appeal to maintain the boundaries between the proper women of a family and a pornē like Neaira (114). The other two uses are generalized statements about pornai and hetairai (112-13; see below). Apollodorus has pointedly refrained from labeling Neaira a porne throughout most of the speech. Rather, he has built up to this verbal assault. The characterization of her as a hetaira throughout the narrative and the use of porne only at the end of the speech produce an extremely forceful attack, which undermines her previously established,

${ }^{31}$ Carey $1992,140$.

${ }^{32}$ Carey $(1992,140-41)$ notes the "striking terminological shift," but he goes on to say that "the distinction will have mattered little to Apollodorus' audience." Although the audience may not have been concerned with the accuracy of this label, this use presumably will have mattered in terms of its effect on the jurors' opinion of Neaira's character. Kapparis says nothing of the use of peporneumenon here. Rather, he points to Carey's commentary on this passage (107) but misplaces it as commentary for passage 114 where Apollodorus uses the noun form pornē in reference to Neaira. Nevertheless, Kapparis' commentary on 114 is a useful discussion of rhetorically attacking Neaira as a porne as opposed to a hetaira $(1999,408-9)$. 
more privileged status of "courtesan" and drags her down to the realm of the lower class "prostitute." 33 The strategy of saving his harsh attacks on Neaira's career for the end of the speech is a sign of Apollodorus' careful attention to timing. ${ }^{34} \mathrm{He}$ has come off a rather weak part of his case against Phano, followed by a long historical analogy, and he is beginning the close of his argument. At this point, where it will be most effective, Apollodorus attempts to leave a lasting impression of Neaira's shamelessness in the minds of the jurors.

The term porne $\bar{e}$, therefore, is not merely a substitute for the term hetaira. Apollodorus is deliberately exploiting the area of overlap between the two terms (the exchange of sex for something else of value) for the purpose of slander. According to Kapparis,

Strictly speaking, Neaira never worked in a brothel (cf. com. 30); on the contrary, she was an expensive courtesan employed by famous and wealthy men, and Apollodoros was well aware of it. When he calls her a porne... his intention is to degrade Neaira ... ${ }^{35}$

Apollodorus uses porne of Neaira, but he is careful not to press this term, recognizing that most of his account only portrays her as a hetaira. Therefore, in his argument at the end of the speech, he only points to three possible identities for Neaira: gune $\bar{e}$ pallake $\bar{e}$, or hetaira.$^{36}$ Nowhere in this important concluding section is there any mention or even a suggestion that Neaira was actually a porne.

${ }^{33}$ Here the objection could be raised that earlier in the narrative (33), Neaira had already demonstrated similarly shameful behavior when she copulated with Phrynion and other symposiasts in public. In this section, however, the attack is directed almost entirely against Phrynion for his outrageous display of privilege and for his mistreatment of Neaira, which resulted in her leaving him. This depiction stands in contrast to that of 107 where Neaira is attacked directly, as is highlighted by the use of milder language in 33 ( $\sigma v v \hat{\eta} v$ and

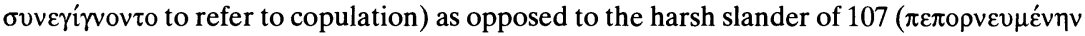
and $i \beta \rho i \zeta o v \sigma \alpha v)$. Cf. section 68 (and n. 19) where Apollodorus similarly directs his attack against Stephanus by calling him a pornoboskos, rather than calling Phano or Neaira pornai.

${ }^{34} \mathrm{Cf}$. [Demosthenes] 48 where the speaker brings in an attack on his opponent's hetaira at the end of the speech.

${ }^{35}$ Kapparis 1999, 409. I agree with Kapparis that Neaira worked as a hetaira once she came of age; however, as I have argued above, I believe she was likely considered a pornē when she worked under Nikaretē given her young age and servile status. Nevertheless, the point here is that Apollodorus did not consider Neaira a porne when she was an adult.

${ }^{36}$ See sections $118-19$, which I discuss below, 31. 
We have seen a specific rhetorical purpose for Apollodorus' use of both terms for one woman, and it is clear that he does not use the terms synonymously or interchangeably. However, there is one passage in the speech where the two terms might be construed as conflated. In section 112, Apollodorus appears to use hetaira and porne without distinction:

For there will then be complete freedom for prostitutes ( $\tau \alpha i \hat{\varsigma} \pi$ ópvaı) to live in marriage with anyone they please and to declare anyone at all the father of their children. And your laws will be invalid, while the characters of courtesans (oi $\delta \grave{\varepsilon} \tau \rho o ́ \pi 0 \imath \tau \hat{\omega} v \dot{\varepsilon} \tau \alpha \iota \rho \hat{\omega} v$ ) will have the power to achieve whatever they wish.

But we must note that this passage is part of the continuation of Apollodorus' slanderous attack on Neaira that began in section 107. At this point, he has already used both terms to describe her, so here we should not be shocked to see a more generalized, rhetorically charged statement likewise making use of both of these terms.

In light of our understanding thus far of how carefully Apollodorus uses prostitution terminology, a reexamination of the famous passage on the tripartite division of women (122) is necessary. Most scholars quote this passage without considering Apollodorus' overall strategy. ${ }^{37}$ It is impossible, however, to understand what he is getting at without looking more closely at the conjunction of the same three terms just a few lines earlier. In speculating about which line of defense Stephanus will take, Apollodorus puts forth the following conjectures:

For myself, I wonder what on earth they will actually say to you in the defense. That this Neaira is of citizen birth and that she lives in marriage with Stephanos according to the laws? But it has been attested that she is

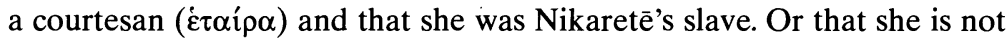

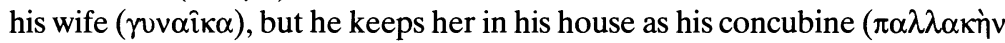

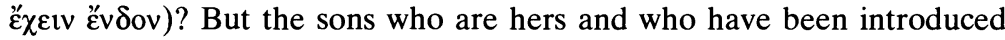
into the phratry by Stephanos and the daughter who was given in marriage to an Athenian male demonstrate quite clearly that he keeps her as his wife ( $\gamma v v \alpha \hat{i} \kappa \alpha)$... but I hear that he intends to offer a defense of this sort,

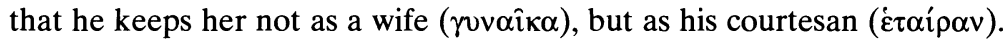

(118-19)

${ }^{37}$ Sealey $(1984,117-19)$ does consider these two passages together. His discussion, however, is focused on showing that the mention of pallake in 118 could be referring implicitly to an alien pallake, since the goal of his paper is to demonstrate that lawful concubinage existed at Athens. 
In this passage, Apollodorus considers whether Stephanus will claim that Neaira is his gune, pallake, or hetaira. In so doing, Apollodorus draws some distinctions between the different types of women. Far from using pallake $\bar{e}$ as interchangeable with hetaira, as Davidson asserts, ${ }^{38}$ he clearly

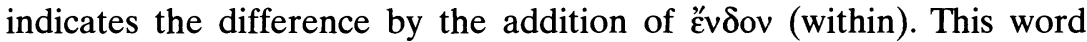
reveals that the pallake normally resided in the home of the man, whereas the hetaira did not. ${ }^{39}$ The same distinction can be seen in other speeches where a man is attacked specifically for bringing a hetaira into the home and living with her. For example, Alcibiades is accused of bringing hetairai home and driving out his wife in [Andocides] 4 (14), and Olympiodorus is attacked for unlawfully living with a hetaira in the home instead of taking a wife according to the laws (53). ${ }^{40}$ Living with a hetaira in one's own home is clearly a different act from visiting one outside the home; ${ }^{41}$

${ }^{38}$ Davidson 1997, 101, with n. 75. Cf. also Ogden 1996, 157: "it is impossible to make any kind of absolute or sustainable categorical distinction between pallakai and hetairai (though, as we saw, the speech against Neaira attempted to make a specious distinction between them)." Ogden sees the former as a subset of the latter.

${ }^{39} \mathrm{Cf}$. Vernant $(1980,57)$ who claims "a clear distinction is made between the concubine and the courtesan, hetaira, the difference being that the concubine cohabits with her man." For scholars who support a distinction, see also Brown 1990, 248-49; Post 1940, 44749; Gomme and Sandbach 1973, 30-31; Hauschild 1933, 7.

${ }^{40}$ [Andocides] 4.14: "Then, after obtaining a dowry such as no Greek had ever obtained before, he behaved in so profligate a fashion, bringing mistresses into the bridal

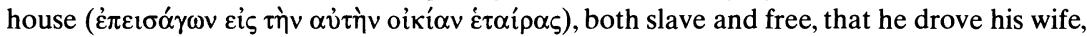
who was a decent woman, to present herself before the Archon, as she was legally entitled to do, and divorce him." [Demosthenes] 48.53: "For you must know, men of the jury, that this fellow Olympiodorus has never married an Athenian woman in accordance with your laws; he has no children nor has he ever had any, but he keeps in his house a courtesan

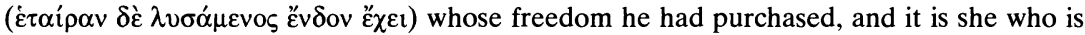
the ruin of us all and who drives the man on to a higher pitch of madness." Note particularly the use of oikí $\alpha v$ in the first example and है $v \delta o v$ in the second to indicate explicitly that the hetairai were "in the home."

${ }^{41}$ See Davidson 1997,99: "It was in fact considered disgraceful to keep a lover in the same house as one's wife or other female relatives." Cf. section 22 where Apollodorus notes that Lysias did not bring Nikaretē and Metaneaira into his home out of respect for his wife and the other women of the house. Cf. also Dem. 40.9 where the speaker praises his father (albeit in a back-handed manner) for not establishing Plangon in his home even after his wife passed away. Hetairai would, of course, enter the home for symposia, and some even lived with bachelors (either before marriage or in their old age). According to Athenaeus, Hypereides, for example, brought Myrrhinẽ into his home and made her his oikouros (Ath. $13.590 \mathrm{c}-\mathrm{d}$ ). Athenaeus, however, is unclear on how socially acceptable or unacceptable this act was. He mentions that Hypereides cast his son, Glaucippus, out of the home before moving Myrrhinē in, which suggests it was not without reproach. Moreover, Hypereides' reputation for consorting with and maintaining many courtesans was likewise not unproblematic. 
having a pallake in the house, however, was a necessity of her function and thus was no cause for shame. ${ }^{42}$

These three possibilities of defense mentioned in 118-19 form the essential background for Apollodorus' proclamation that there are three categories of women:

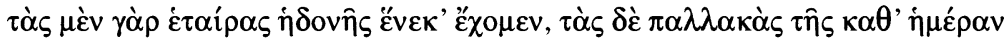

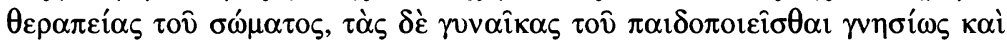

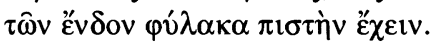

For we have courtesans for pleasure, and concubines for the daily service of our bodies, [and] wives for the production of legitimate offspring and to have a reliable guardian of our household property. ${ }^{43}$

Commenting on this passage, Carey (like Davidson) sees no significant difference between the pallake and the hetaira, asserting that "[Apollodorus'] distinction between pleasure (from the hetaira) and servicing of the body (from the pallake $)$, both of which refer to sexual gratification, is artificial." ${ }^{44}$ But if we keep in mind that the pallake lived with the man in the home ${ }^{45}$ then we do not need to see "daily therapy of the body" as purely sexual. Certainly her duties would involve non-sexual activities as well, such as bathing the man, serving food, and keeping his clothes clean, etc. ${ }^{46}$ The distinction made by Apollodorus is valid and relevant.

42 See Post 1940, 445, and Gomme and Sandbach 1973, 31: “... no discredit attached to the man who lived with a pallake.". But see Patterson $(1991,284)$ who points out "... actually keeping a slave concubine in the house together with a citizen wife does not seem to be common practice in classical Athens."

${ }^{43}$ As Carey points out (1992,148-49), childbearing was the principal role of the wife, but the extent to which she guarded possessions would have depended more on custom and the individuals themselves. We may ask here why Apollodorus chooses to include the role of guarding possessions (considering that he only mentions one function for the other two groups) when the legitimacy of children is the main issue at hand. Aside from the fact that this secondary role was a known part of a wife's duty, here in particular it would serve as another contrast to the hetaira. Stereotypically, the hetaira is depicted and slandered (in many genres of literature, including oratory and comedy) as a drain on the household goods because the husband had to keep her constantly lavished with gifts.

${ }^{44}$ Carey 1992, 148; Vernant $(1980,58)$ also sees the distinction as purely rhetorical based on Apollodorus' ambiguous definition of pallake $\overline{\text {. }}$

${ }^{45} \tau \hat{\imath} \varsigma \kappa \alpha \theta^{\prime} \dot{\eta} \mu \varepsilon \varepsilon_{\rho} \alpha \nu \theta \varepsilon \rho \alpha \pi \varepsilon i \alpha \varsigma$ clearly implies that the pallake was in the home if she were to provide services daily. Notice also that $\varepsilon^{\prime} \delta \delta \mathrm{v}$ is mentioned again in conjunction with the wife, solidifying the fact that it is used to indicate a woman who lives "in the home."

${ }^{46}$ The pallake in Antiphon 1 demonstrates this quite clearly; she serves her master Philoneus and his friend dinner and (fatally) fills their cups (17-19). Cf. Mossé $(1991,277)$ who points to the Homeric origin of the term and the types of care of the body these women would provide: "ces servantes privilégiées préparaient le bain du maitre de maison." 
Kapparis does much better to identify a distinction among all three. ${ }^{47}$ Yet he too seems bound by the need to explain this passage as inclusive of all women in Athenian society. For example, he states that "the term 'hetaira' encompasses all forms of prostitution ... this very diverse group would range from expensive courtesans to common prostitutes established in brothels." ${ }^{48}$ But why should we force ourselves to think Apollodorus is speaking of any other women besides hetairai? Certainly this statement need not also include pornai. In fact, Apollodorus does not mention pornai, not because he sees them as included with hetairai, but rather because Neaira was not a porne (as Kapparis himself has argued) and thus this group is irrelevant here. ${ }^{49}$ By ignoring Apollodorus' careful distinctions among terms, scholars have obscured our understanding of the differences between types of prostitutes, and women's roles more generally, which are identifiable from the text itself.

One last question remains: if Apollodorus is distinguishing between pallake $\bar{e}$ and hetaira, why did Apollodorus not attack Neaira as Stephanus' pallake instead of his hetaira since, even as his pallake , she would not have been able to produce legitimate children $?^{50}$ The answer

${ }^{47}$ Contra Carey $(1992,148)$ who sees the first two statements as contrasted with the last; Kapparis $(1999,422-23)$ rightly sees the last $\tau \grave{\alpha} \varsigma \delta \varepsilon$ as connective and not adversative.

${ }^{48}$ Kapparis 1999, 422-23. Similarly, Gomme and Sandbach 1973, 30-31.

${ }^{49}$ In a similar vein, Carey $(1992,148)$ argues that there is overlap in the usage of the terms pallake and hetaira by pointing to sections 39 and 119 where he claims Neaira is called a hetaira, but the description in these passages more accurately fits that of pallake But if this is true about 39, it simply confirms Apollodorus' rhetorical strategy of consistently depicting Neaira as a hetaira throughout the narrative. Never in the speech does he call her a pallake ; the term only appears as a theoretical construct. And in 118-19, as I have argued above, Apollodorus himself makes a clear differentiation between the two terms. See Brown $(1990,249)$ who discusses a similar situation in Menander's Samia where Chrysis is labeled both a hetaira and a pallake at different points in the play (cf. Hauschild 1933, 56-58). Like Neaira, Chrysis blurs boundaries between the two roles when she is installed in the home of Demeas. Brown argues that "the transition from prostitute to concubine was not necessarily definitive or permanent." He goes on to say, "as far as I am aware it would not have been normal to refer to all pallakai as hetairai."

${ }^{50}$ Here the law mentioned in Dem. 23.53 is relevant; it states that a man is not subject to trial if he kills another man for having intercourse with his pallake who is the bearer of free offspring (cf. Lys. 1.31). This law still existed but was likely to have been superseded by Pericles' laws on citizenship. Sealey $(1984,113-16)$ puts forth the possibility that the children of a citizen/free pallake would also have been recognized as citizens, based on a passage in Isaeus (3.39) that mentions citizens giving their own women into pallakia. Ogden $(1996,158-61)$ is rightfully skeptical. Nonetheless, Apollodorus has already argued at length that Neaira was an alien. Thus, whether or not citizen pallakai in general could have produced legitimate offspring, Neaira herself would not have been eligible (cf. Mossé 1991). 
is simply because she was not a pallakē. If we can trust Apollodorus' last comment on Stephanus' likely defense in section 119 ["but I hear that he intends to offer a defense of this sort, that he keeps her not as a wife

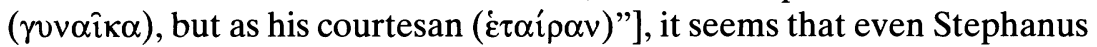
did not consider Neaira his pallakè. As Patterson has shown, the pallake remained a servile position even into the classical period and furthermore, one which was probably not common. ${ }^{51}$ Neaira's status as a free, independent woman clearly separates her from this role. Apollodorus' consistent depiction of her as a hetaira and not a pallake is a further indication of this. The confusion comes from the fact that she lives in his home, and thus we see the conjecture of Apollodorus that Stephanus might argue that she was his pallake. This conjecture does not mean, however, that there was no distinction between pallake and hetaira or hetaira and porne, for that matter. Although the boundaries between these roles would not have been clearly defined, we have seen definite features that differentiate these positions from one another. We have also seen that Apollodorus is consistent in keeping to those distinctions.

I have attempted to show first, that Apollodorus does not use the terms pornē, hetaira, and pallake interchangeably in the text, and second, that we can identify interesting distinctions between these terms by understanding how carefully he does use them. To what extent these distinctions existed in Athenian social reality is a different question. We must always be aware that the orator simplifies these categories and exaggerates the distinctions between and among them for the needs of his case. But behind the rhetoric, as always, are the social conditions that would be recognizable and believable by the jurors. Keeping this in mind, greater progress will be made at understanding prostitution and women's roles in society if scholars continue to examine the terminology of prostitution more closely within its oratorical context. ${ }^{52}$

University of TeXas at Austin

e-mail: jminer@mail.utexas.edu

${ }^{51}$ Patterson 1991,282-85. Cf. Ant.1.14 where Philoneus threatens to install his pallakē into a brothel, thus demonstrating his control over her.

${ }^{52}$ An earlier version of this paper was delivered at CAMWS 2000 where I received helpful feedback. I would like to thank the anonymous referees at $A J P$ for their suggestions. I am especially grateful to Michael Gagarin for his insightful comments and criticism at all stages of this paper. 


\section{BIBLIOGRAPHY}

Blass, Friedrich. 1893. Die Attische Beredsamkeit. Leipzig: B. G. Teubner.

Brown, Peter. 1990. "Plots and Prostitutes in Greek New Comedy." In Papers of the Leeds International Latin Seminar, ed. Francis Cairns. ARCA 29:24166.

Calame, Claude. 1989. "Entre rapports de parenté et relations civiques: Aphrodite l' hetaïre au banquet politique des hétairoi." In Aux sources de la puissance: Sociabilité et parenté, 101-11. Rouen: L'Université de Rouen.

Carey, Christopher. 1992. Apollodoros Against Neaira: [Demosthenes] 59. Warminster: Aris \& Phillips.

Cohen, E. E. 2000. "Whoring Under Contract: The Legal Context of Prostitution in Fourth Century Athens." In Law and Social Status in Classical Athens, ed. Virginia Hunter and Jonathan Edmondson, 113-47. Oxford: Oxford University Press.

Davidson, James. 1997. Courtesans and Fishcakes. London: HarperCollins.

Dover, K. J. 1973. "Classical Greek Attitudes to Sexual Behaviour." Arethusa 6:59-73.

. 1989. Greek Homosexuality. 2d ed. Cambridge, Mass.: Harvard University Press.

Fisher, Nick. 2001. Aeschines: Against Timarchos. Oxford: Oxford University Press.

Gilhuly, Catherine. 1999. "Representations of the Hetaira." University of California at Berkeley: Ph.D. diss.

Gomme, A. W. and Sandbach, F. H. 1973. Menander: A Commentary. Oxford: Oxford University Press.

Hauschild, Hans. 1933. Die Gestalt der Hetäre in der griechischen Komödie. Leipzig: C. \& E. Vogel.

Herter, Hans. 1957. "Dirne.” Reallexikon für Antike und Christentum 3:1181-82. Stuttgart: Hiersemann.

Kapparis, K. A. 1995. "Critical notes on D.59 'Against Neaira.'” Hermes 123:20 27.

1999. Apollodoros: "Against Neaira" [D 59]. Berlin: Walter de Gruyter.

Kurke, Leslie. 1999. Coins, Bodies, Games, and Gold. Princeton: Princeton University Press.

Mossé, Claude. 1991. "La place de la pallake dans la famille athénienne." In Symposion 1990, ed. Michael Gagarin, 273-79. Cologne: Böhlau.

Ogden, Daniel. 1996. Greek Bastardy. Oxford: Clarendon Press.

Patterson, Cynthia. 1991. "Response to Claude Mossé." In Symposion 1990, ed. M. Gagarin, 281-87. Cologne: Böhlau.

. 1994. "The Case against Neaira and the Public Ideology of the Athenian Family." In Athenian Identity and Civic Ideology, ed. Alan Boegehold and Adele Scafuro, 199-216. Baltimore: Johns Hopkins University Press.

Peschel, Ingeborg. 1987. Die Hetäre bei Symposion und Komos in der attisch- 
rotfiguren Vasenmalerei des 6.-4. Jahrhunderts vor Christus. New York: Peter Lang.

Post, L. A. 1940. "Woman's Place in Menander's Athens." TAPA 71:420-59.

Sealey, Raphael. 1984. "On Lawful Concubinage in Athens." ClAnt 3:111-33.

Vernant, J. P. 1980. Myth and Society in Ancient Greece. London: Harvester Press. 